\title{
Population Diallel of Elite Medium- and Long-Duration Pearl Millet Composites: I. Populations and Their $F_{1}$ Crosses
}

\author{
Adam Mohamed Ali, C. Tom Hash,* Abu Elhassan S. Ibrahim, and A. G. Bhasker Raj
}

\begin{abstract}
Pearl millet [Pennisetum glaucum (L.) R. Br.] varieties grown in semiarid Africa and Asia have low grain yields. Information on heterosis and combining ability of diverse open-pollinated cultivars, breeding populations, and genepools is needed for efficient choice of breeding methods and parental materials to use in developing productive base populations for this crop. Data for grain and biomass yield, growth rate, time to flowering, plant height, panicle length, and productive tillers were collected from an 11-parent variety cross diallel of diverse pearl millet populations evaluated in five field environments in peninsular India. Data were summarized using the Gardner-Eberhart Analysis II. When genotype $\times$ environment interactions were significant, ranks of parental general combining abilities (GCA) were used to identify particular environments and parents contributing most to these interactions. Parental population effects were significant for all characters, as were differences in GCA. Populations NWC C2, AfPop 88, and LHGP consistently had the poorest ranks for general combining ability for grain yield across test environments. Populations ICMV 91059, SenPop, ICMP 91751, and ICMP 92951 constitute a genetically diverse subset of the parents that consistently had the best ranks for grain yield GCA across test environments. With ICMV 155 (crosses of which performed poorly in only one of five test environments), this latter group is a good source of more broad-based breeding populations for dual-purpose pearl millet improvement targeting peninsular India.
\end{abstract}

$\mathrm{P}$ EARL MILLET is a robust, diploid, cross-pollinated grass with immense genetic diversity. It is grown as a subsistence grain and stover crop, primarily in subSaharan Africa and South Asia (Rachie and Majmudar, 1980; FAO/ICRISAT, 1996; Rai et al., 1999). It is one of six crops in the research mandate of the International Crops Research Institute of the Semi-Arid Tropics (ICRISAT). Its bisexual protogynous flowers, large seed numbers (up to 3000 per panicle), excellent tillering ability (four to six effective tillers per plant), and low seed rate make pearl millet amenable to genetic improvement by recurrent selection (Burton, 1983). A wide range of improved pearl millet populations have been developed by ICRISAT and national program plant breeders in Africa and Asia (Rai and Anand $\mathrm{Ku}$ mar, 1994; Rattunde et al., 1997). This study was initiated to evaluate opportunities for merging several of these populations having medium-to-long duration (85

Adam Mohamed Ali, Agricultural Research Corporation, Wad Medani, Sudan; C. Tom Hash and A.G. Bhasker Raj, Genetic Resources and Enhancement Program, ICRISAT, Patancheru, AP 502 324, India; and Abu Elhassan S. Ibrahim, Faculty of Agricultural Sciences, Univ. of Gezira, Wad Medani, Sudan. ICRISAT Journal Article no. 2246. Reports thesis research submitted by A.M. Ali in partial fulfilment of requirements for the M.S. degree at the Univ. of Gezira, Wad Medani, Sudan. This research was supported in part by the UNDP/RAB/88/003 Sorghum and Millet Development Project. Received 19 Oct. 1999. *Corresponding author (c.t.hash@cgiar.org).

Published in Crop Sci. 41:705-711 (2001). to $110 \mathrm{~d}$ to maturity in peninsular India) to provide a smaller, more manageable number of genetically broad, high-yielding base populations for future use in recurrent selection programs targeting dual-purpose pearl millet cultivars for traditional and nontraditional pearl millet production environments.

\section{MATERIALS AND METHODS}

\section{Genetic Materials}

Eleven diverse, medium- and long-duration pearl millet populations (Table 1 ) were crossed in a diallel without reciprocals during the 1993 summer (dry) season at ICRISAT, Patancheru, India. Parental populations having medium-to-long duration suited to peninsular-Indian conditions were selected on the basis of their grain yield, panicle characteristics, growth rates, and resistance to fungal diseases caused by Sclerospora graminicola (Sacc.) J. Schröt., Moesziomyces penicillariae (Bref.) K. Vánky, and Claviceps fusiformis Loveless. Populations were intercrossed using bulk pollen from 100 to 120 plants in each population to pollinate an equal number of plants in each of the other parental populations. The pollenstorage technique (Hanna, 1990) was used to facilitate crossing when the flowering times for certain parental population pairs were too far apart.

\section{Field Trials}

The resulting $55 \mathrm{~F}_{1}$ population crosses and their 11 parents were evaluated for 13 agronomic characters (Table 2) in replicated trials conducted across five environments [1993 rainy season at two sites (Patancheru, $18^{\circ} \mathrm{N}, 78^{\circ} \mathrm{E}$; and Bhavanisagar, $\left.11^{\circ} \mathrm{N}, 77^{\circ} \mathrm{E}\right) ; 1994$ dry summer season, and 1994 and 1995 rainy seasons at one site (Patancheru)] in peninsular India. In each environment, the 66 entries (genotypes) were evaluated in three replications of 4-row by 4-m plots arranged in a randomized complete block design. Between-row spacing was $75 \mathrm{~cm}$; within-row spacing was $15 \mathrm{~cm}$; and 1-m alleys separated the plots. The soil type at Patancheru was a light-textured, red Alfisol. The soil type at Bhavanisagar was an Alfisol. The Bhavanisagar location environment was dry, cool, and overcast, and it was managed as fully irrigated. The 1994 dry summer season environment at Patancheru was characterized by high temperatures, low humidity, and limited cloud cover, and it was managed as fully irrigated. Intermediate temperatures and high humidity with more cloud cover characterized the three rainy-season environments at Patancheru, which were not irrigated.

Plant counts were taken from the two central rows of each plot after thinning to determine the actual plant population. Flowering time and plant height were assessed on a wholeplot basis (Table 2). At maturity, panicles in the two central rows were cut, sun-dried, weighed, and threshed to determine the grain yield per plot. Stover of the harvested rows was

Abbreviations: $\mathrm{CV}$, coefficients of variation; $\mathrm{C}_{\mathrm{n}}$, cycle $\mathrm{n}$; GCA, general combining ability; $\mathrm{G} \times \mathrm{E}$, genotype $\times$ environment; ICRISAT, International Crops Research Institute for the Semi-Arid Tropics; SCA specific combining ability; TTF, time to flowering. 
Table 1. Characteristics, origins, and genetic background of 11 pearl millet parental populations of diallel crosses.

\begin{tabular}{|c|c|c|c|}
\hline Name & Origin & Characteristics & Reference \\
\hline AfPop 88 & ICRISAT & $\begin{array}{l}\text { Very tall, very long duration feeder population developed by random mating } \\
\text { inbred bulks selected at ICRISAT-Patancheru from breeding materials } \\
\text { received from various locations in western and central Africa }\end{array}$ & Rai and Anand Kumar, 1994 \\
\hline AfPop 90 & ICRISAT & $\begin{array}{l}\text { Very tall, very long duration, feeder population developed by random mating } \\
\text { inbred bulks selected at ICRISAT-Patancheru from breeding materials } \\
\text { received from Zambia and Zimbabwe }\end{array}$ & Rai and Anand Kumar, 1994 \\
\hline ICMP 87200 & ICRISAT & $\begin{array}{l}\text { Long duration, tall, dual-purpose population, with long panicles; resistant to } \\
\text { downy mildew, smut and ergot; } \text { C }_{0} \text { random-mated bulk of the ICRISAT } \\
\text { Ergot Resistant Composite (ERC) }\end{array}$ & Rai and Anand Kumar, 1994 \\
\hline ICMP 87307 & ICRISAT & $\begin{array}{l}\text { Full season, tall, elite dual-purpose population with long, compact panicles, } \\
\text { and medium grain size; } \text { C }_{7} \text { random-mated bulk of the ICRISAT } \\
\text { Intervarietal Composite (IVC) }\end{array}$ & Rai and Anand Kumar, 1994 \\
\hline ICMP 91751 & ICRISAT & $\begin{array}{l}\text { Medium-long duration, tall, elite dual-purpose population with long medium- } \\
\text { compact panicles and very high grain yield potential; resistant to downy } \\
\text { mildew and smut; } C_{1} \text { random-mated bulk of the ICRISAT Smut } \\
\text { Resistant Composite II (SRC II) }\end{array}$ & Rai and Anand Kumar, 1994 \\
\hline ICMP 92591 & ICRISAT/Zambia & $\begin{array}{l}\text { Tall, long-duration, elite dual-purpose population with long cylindrical } \\
\text { panicles and high grain yield potential; } C_{1} \text { random-mated bulk of } \\
\text { Lubasi (Late Backup Synthetic) }\end{array}$ & Monyo, 1998 \\
\hline ICMV 155 & ICRISAT & $\begin{array}{l}\text { High yielding, downy mildew resistant, dual-purpose medium-duration } \\
\text { cultivar released in India; bred by modified mass selection within } C_{4} \\
\text { of the ICRISAT New Elite Composite (NELC) }\end{array}$ & $\begin{array}{l}\text { Pheru Singh et al., 1994; Rai } \\
\text { and Anand Kumar, } 1994\end{array}$ \\
\hline ICMV 91059 & ICRISAT & $\begin{array}{l}\text { Medium-duration dual-purpose experimental variety with high grain yield } \\
\text { potential; reselected from ICMS 8359, which was bred by random } \\
\text { mating pedigree-derived inbred lines unrelated to the remaining ten } \\
\text { parental populations in this study }\end{array}$ & None \\
\hline LHGP & $\begin{array}{l}\text { ICRISAT Genetic } \\
\text { Resources } \\
\text { Division }\end{array}$ & $\begin{array}{l}\text { Very tall, very long duration genepool with large panicles; developed by } \\
\text { four generations of random mating of } 804 \text { genebank accessions selected } \\
\text { for long }(>55 \mathrm{~cm}) \text {, thick }(>35 \mathrm{~mm}) \text { panicles (ICRISAT Large Headed } \\
\text { Gene Pool) }\end{array}$ & Appa Rao et al., 1998 \\
\hline NWC C2 & Nigeria & $\begin{array}{l}\text { Medium-long duration, tall, dual-purpose population; } \mathrm{C}_{2} \text { random-mated } \\
\text { bulk of the Nigerian World Composite }\end{array}$ & None \\
\hline SenPop & ICRISAT & $\begin{array}{l}\text { Long duration feeder population with high vegetative growth rate and high } \\
\text { grain yield potential; } \mathrm{C}_{0} \text { bulk developed by back-crossing and } \\
\text { selection involving a weedy selection from Senegal and the } F_{1} \text { of the variety } \\
\text { cross between ICMV } 87901 \text { (from the ICRISAT Bold Seeded } \\
\text { Early Composite) and ICMV } 82132 \text { (from the ICRISAT Smut Resistant } \\
\text { Composite, released in Zambia as 'Kaufela') }\end{array}$ & $\begin{array}{l}\text { Rai and Anand Kumar, 1994; } \\
\text { Weltzien Rattunde et al., } \\
\text { 1995; Lynch et al., 1995; } \\
\text { Monyo, } 1998\end{array}$ \\
\hline
\end{tabular}

cut and dried to assess dry-matter yield. Growth index was calculated as described by Bramel-Cox et al. (1984).

\section{Statistical Analysis}

Analyses of variance were first performed on data from individual environments using Genstat Version 4, from Rothamsted Experimental Station, and Analysis II proposed by Gardner and Eberhart (1966) and Eberhart and Gardner (1966). Genetic parameters were estimated by fitting the population and population cross means to the fixed linear model:

$$
Y_{i j}=\mu_{\mathrm{v}}+0.5\left(V_{i}+V_{j}\right)+k\left(h+h_{i}+h_{j}+s_{i j}\right)
$$

where $Y_{i j}$ is the mean of the cross between the $i$ th and $j$ th parental populations; $\mu_{\mathrm{v}}$ is the mean of all parental populations; $V_{i}$ and $V_{j}$ are the varietal effects of parental population $i$ and parental population $j ; h$ is the average heterosis contrib- uted by all parental populations used in crosses; $h_{i}$ and $h_{j}$ are the average contributions of individual parental populations to the expression of heterosis; $s_{i j}$ is the specific heterosis (specific combining ability, SCA) that occurs when parental population $i$ is crossed to parental population $j$; and $k=0$ when $i=j$, and $k=1$ when $i=j$.

Genotype effects $\left(G_{i j}, 65 \mathrm{df}\right)$ were first partitioned into varietal population effects $\left(V_{i}, 10 \mathrm{df}\right)$, and heterosis effects $\left(h_{i j}, 55 \mathrm{df}\right)$. Heterosis effects were further partitioned into average heterosis $(h, 1 \mathrm{df})$, variety heterosis $\left(h_{i}, 10 \mathrm{df}\right)$, and specific heterosis $\left(s_{i j}, 44 \mathrm{df}\right)$ effects.

Following the within-environment analyses for each character studied, combined analyses across environments were performed when error variances were homogenous. Environmental effects were considered to be random. Bartlett's test (Steel and Torrie, 1980, sect. 20.3) was used for assessing homogeneity of variance and the magnitude of genotype $\times$ environment

Table 2. Agronomic characteristics measured in two or more environments in this study.

\begin{tabular}{|c|c|c|}
\hline Trait & Method of measurement and/or calculation & Units \\
\hline Plant count & Number of plants from two rows of $5 \mathrm{~m}$, measured two to three weeks after thinning & \\
\hline Time to flowering (TTF) & Days after emergence when $75 \%$ of plants had emerging stigmas & d \\
\hline Panicle count & Number of panicles from two rows of $5 \mathrm{~m}$, measured two weeks before harvest & \\
\hline Plant height & Average of plants per plot for distance from soil surface to top of primary panicle & $\mathbf{c m}$ \\
\hline Panicle length & Mean length of ten main-culm panicles in each plot & cm \\
\hline Panicle yield & Mass of panicles from two rows of $5 \mathrm{~m}\left(\right.$ net plot area $\left.=7.5 \mathrm{~m}^{2}\right)$ & g \\
\hline Grain yield & Mass of grains from two rows of $5 \mathrm{~m}$ (net plot area $=7.5 \mathbf{~ m}^{2}$ ) & g \\
\hline Straw yield & Vegetative dry matter at maturity from two rows of $5 \mathrm{~m}$ (net plot area $\left.=7.5 \mathrm{~m}^{2}\right)$ & $\mathbf{g}$ \\
\hline Grain yield per season & (Grain yield per plot/plot area)*10 & $\mathbf{k g ~ h a}^{-1}$ \\
\hline Grain yield per day & Grain yield per season/(TTF +25$)$ & $\mathbf{k g ~ h a}^{-1} \mathbf{d}^{-1}$ \\
\hline Productive tillers & Panicle count/plant count & No. plant ${ }^{-1}$ \\
\hline Biomass & $(($ Panicle yield + straw yield $) /$ plot area $) * 10$ & $\mathbf{k g ~ h a ~}^{-1}$ \\
\hline Growth index & $($ Biomass $/($ TTF +10$)) /$ plot area & $\mathbf{g ~ m}^{-2} \mathbf{d}^{-1}$ \\
\hline
\end{tabular}


$(\mathrm{G} \times \mathrm{E})$ interaction mean squares. When the interaction was significant, it was used for testing significance of genotype mean squares and all the components. The $\mathrm{G} \times \mathrm{E}$ mean squares were used instead of the residual mean squares to calculate standard errors. General combining ability (GCA) for each parental population $i$ was estimated as $g_{i}=0.5 V_{i}+$ $h_{i}$. When $\mathrm{G} \times \mathrm{E}$ interaction effects were significant for a particular agronomic character, important sources of variation (i.e., particular parents and/or particular environments) contributing most to these interactions were identified by examining graphs of environment-wise rankings of the parental populations for GCA for that character following procedures outlined by Kang and Gauch (1996).

\section{RESULTS AND DISCUSSION}

Coefficients of variation (CV) were $<13 \%$ for individual environments (data not shown) for most characters studied, except for productive tillers and panicle length, for which the CV were $>18 \%$. Combined analyses of variance for eight agronomic characters measured over two to five environments are presented in Table 3 . Genotype $\times$ environment interactions were significant for all characters except productive tillers, biomass, and growth index (the latter two characters were measured in only two environments), indicating that the relative performance of genotypes differed in the test environments. Although statistically significant for five characters, these $\mathrm{G} \times \mathrm{E}$ interactions were large enough to be of practical importance only in the case of grain yield (per season and per day) and plant height.

Genotype $\times$ environment interactions for grain yield per season did not seriously affect GCA ranks of the 11 parental populations for this character across the five environments in this study. The possible exceptions were parental populations ICMV 155, ICMP 92591, and ICMP 87307 (and perhaps ICMV 91059) at Bhavanisagar (Fig. 1a; Table 4). A large portion of the $\mathrm{G} \times \mathrm{E}$ interaction for grain yield per season was due to the failure of ICMV 155 to perform consistently. This elite open-pollinated variety seemed to confer specific adaptation to Patancheru, but its crosses performed poorly at Bhavanisagar. Grain yield per season GCA rankings (Fig. 1a; Table 4) show a similar pattern across environments to those for grain yield per day (Fig. 1b; Table
4) for these parental populations. Five parental populations were major contributors to the $\mathrm{G} \times \mathrm{E}$ interaction for grain yield per day: ICMV 91059, ICMP 92591 , ICMV 155, ICMP 87307, and AfPop 90. Population AfPop 90 appeared particularly poorly adapted to the Patancheru rainy season environments, whereas ICMV 155 and ICMV 91059 appeared particularly poorly adapted to the overcast, shorter day length, Bhavanisagar environment to which ICMP 92591 and ICMP 87307 appeared particularly well adapted. The GCA effects of SenPop for grain yield per season were consistently good in all test environments, indicating the wide adaptation and high potential of this feeder population (broad-based composite of intermediate eliteness, from which superior progenies are extracted to diversify more elite populations) for use as a parent in developing populations and hybrids with high-yield potential (Fig. 1a; Table 4). Populations ICMV 91059, SenPop, and ICMP 91751 and their crosses tended to give consistently high grain yields per season in all test environments, whereas LHGP, AfPop 88, and NWC C2 and their crosses yielded poorly in all test environments. Between these two groups of parental populations were a consistently intermediate group of populations (i.e., AfPop 90 and ICMP 87200) and an inconsistent group comprising ICMV 155, ICMP 92591, and ICMP 87307 that were major contributors to $\mathrm{G} \times \mathrm{E}$ interactions for grain yield (per season and per day) due to the markedly different performances of these populations and their crosses at Patancheru and Bhavanisagar.

The variation in GCA-rank order of parental populations across environments was much less for flowering time (Fig. 1c; Table 4) and plant height (Fig. 1d; Table 4). For plant height, ICMP 87307 and AfPop 88 (and to a lesser extent SenPop, ICMP 91751, and AfPop 90) contributed much of the variation in rank order and hence much of the $G \times E$ interaction. Although statistically significant (Table 3 ), the $\mathrm{G} \times \mathrm{E}$ interactions for flowering time were small and of little practical importance (Fig. 1c; Table 4), as was also observed for panicle length (not shown).

Ouendeba et al. (1996) compared the diallel varietycross Analysis II of Gardner and Eberhart (1966) with the more traditional Analysis III (Gardner and Eber-

Table 3. Mean squares of grain yield per season, grain yield per day, time to flowering, plant height, panicle length, productive tillers, biomass, and growth index for 11 pearl millet populations and their 55 diallel crosses, excluding reciprocals, evaluated across two to five environments $\dagger$ (E) at Patancheru and Bhavanisagar in peninsular India, during 1993 to 1995.

\begin{tabular}{|c|c|c|c|c|c|c|c|c|c|}
\hline \multirow{2}{*}{$\begin{array}{l}\text { Source of } \\
\text { variation }\end{array}$} & \multirow[b]{2}{*}{ df $\dagger$} & \multicolumn{2}{|c|}{ Grain yield } & \multirow{2}{*}{$\begin{array}{c}\text { Time to } \\
\text { flowering }\end{array}$} & \multirow{2}{*}{$\begin{array}{c}\text { Plant } \\
\text { height }\end{array}$} & \multirow{2}{*}{$\begin{array}{l}\text { Panicle } \\
\text { length }\end{array}$} & \multirow{2}{*}{$\begin{array}{l}\text { Productive } \\
\text { tillers }\end{array}$} & \multirow[b]{2}{*}{ Biomass } & \multirow{2}{*}{$\begin{array}{l}\text { Growth } \\
\text { index }\end{array}$} \\
\hline & & per season & per day & & & & & & \\
\hline & & \multicolumn{2}{|c|}{$\mathrm{kg} \mathrm{ha}^{-1}$} & d & - & & \# plant $^{-1}$ & $\mathbf{k g ~ h a}^{-1}$ & $\mathrm{~g} \mathrm{~m}^{-2} \mathbf{d}^{-1}$ \\
\hline Genotypes (G) & 65 & $78956 * *$ & $22.55 * *$ & $16.48 * *$ & $229 * *$ & $17.5 * *$ & $67.7 * *$ & $604145 * *$ & $67.7 * *$ \\
\hline Populations $\left(\mathbf{V}_{\mathrm{i}}\right)$ & 10 & $385658 * *$ & $125.62 * *$ & $99.01 * *$ & $11368 * *$ & $103.6 * *$ & 226.1** & 2109850 ** & $226.1 * *$ \\
\hline Heterosis $\left(h_{i j}\right)$ & 55 & $23192 *$ & 3.81 & $1.48 * *$ & 22 & 1.8 ** & 38.9 & 330362 & 38.9 \\
\hline Average $(h)$ & 1 & $83616 *$ & 11.31 & $6.52 * *$ & 12 & 0.9 & 11.3 & 661504 & 11.3 \\
\hline Population $\left(h_{i}\right)$ & 10 & 16662 & 3.52 & $3.40 * *$ & $33 * *$ & 0.9 & 46.9 & $632166^{* *}$ & 46.9 \\
\hline Specific $\left(s_{i j}\right)$ & 44 & 23305 & 3.71 & $0.93^{* *}$ & 20 & $2.1 * *$ & 37.7 & $254247 *$ & 37.7 \\
\hline $\mathbf{G} \times \mathbf{E}$ & $259(65)$ & $16913 * *$ & 3.30*** & $\mathbf{0 . 5 6 * *}$ & $20 * *$ & $0.6 * *$ & 28.3 & 220061 & 28.3 \\
\hline Pooled error & $648(260)$ & 12236 & 2.14 & 0.13 & 11 & 0.5 & 30.3 & 182833 & 30.3 \\
\hline
\end{tabular}

*, ** Significant at the 0.05 and 0.01 levels of probability, respectively.

† When the degrees of freedom (df) for characters differ, the numbers enclosed in parentheses are those for biomass and growth index, which were evaluated in only two environments. 

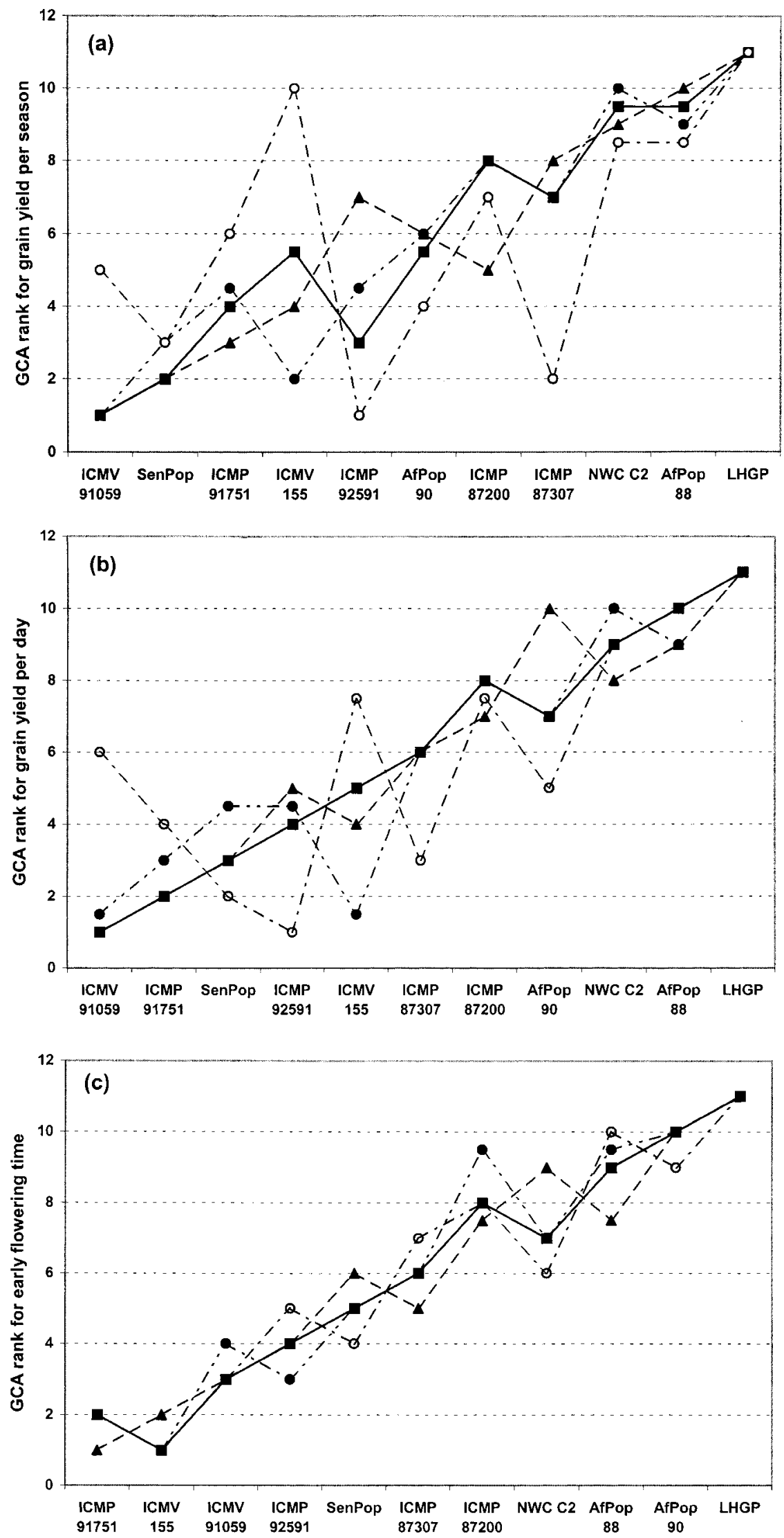

Fig. 1. Continued. 




Fig. 1. Ranked estimates of general combining ability effects for (a) grain yield per season, (b) grain yield per day, (c) time to flowering, and (d) plant height based on evaluation of $\mathbf{1 1}$ pearl millet parental populations and their $\mathbf{5 5}$ crosses across five environments in peninsular India during 1993 to 1995. For each character, the 11 parental populations are arranged along the $x$-axis in rank order (from lowest to highest) of the sums of their ranks for general combining ability effects for that character across all five environments. Deviations from a 1:1 line are indicative of rank-change-type genotype $\times$ environment interactions for that character. Key: $\square=$ ranked sum of ranks across all five environments; $\Delta=$ ranked sum of ranks across three rainy season environments (not irrigated) at Patancheru; $\bullet=$ ranks in one irrigated hot dry season at Patancheru; $\bigcirc=$ ranks in one irrigated cool dry season at Bhavanisagar.

hart, 1966) that first separates parents and crosses before partitioning the latter into GCA and SCA. They observed that the average heterosis sum of squares of the former analysis is equal to the parents vs. crosses contrast of the latter, and that specific heterosis is equal to SCA, whereas the other two components of the genotype effects of the Analysis II (i.e., varietal effects of the parental populations and population heterosis effects) are different from any provided by the more traditional Analysis III. Assuming a restricted genetic model of additive and dominance effects only, these latter two sources of variation in the Gardner-Eberhart Analysis II give a better separation of additive and dominance effects than can be otherwise obtained from the current data set without resorting to additional experiments involving additional inbred populations. Under these as- sumptions, the heterosis terms in the Gardner-Eberhart Analysis II are all due to dominance and differences in allelic frequencies between pairs of parental populations, and the mean squares for $V_{i}$ effects of the parental populations contain all variation due to additive genetic effects (as well as some dominance). Hence we examined these two sources of variation ( $V_{i}$ and heterosis) for each of the eight agronomic characters analyzed in this pearl millet variety-cross diallel.

Parental populations differed $(P<0.01)$ for all eight characters, as indicated by the highly significant $V_{i}$ effects (Table 3 ). Heterosis effects $\left(h_{i j}\right)$ were significant for grain yield per season, time to flowering, and panicle length. Average heterosis effects $(h)$ were significant only for grain yield per season and time to flowering, while $h_{i}$ and/or $s_{i j}$ effects were significant for time to

Table 4. Environment-wise ranks of general combining ability effects for grain yield per season, grain yield per day, time to flowering, and plant height for 11 pearl millet populations evaluated (with their 55 diallel crosses, excluding reciprocals) across five environments $\dagger$ at Patancheru and Bhavanisagar in peninsular India, during 1993 and 1995.

\begin{tabular}{|c|c|c|c|c|c|c|c|c|c|c|c|c|c|c|c|c|}
\hline \multirow[b]{2}{*}{ Environment $\dagger$} & \multicolumn{4}{|c|}{ Grain yield per season } & \multicolumn{4}{|c|}{ Grain yield per day } & \multicolumn{4}{|c|}{ Time to flowering } & \multicolumn{4}{|c|}{ Plant height } \\
\hline & $\begin{array}{l}\text { All } \\
\text { (5) }\end{array}$ & $\begin{array}{l}\text { PR } \\
\text { (3) }\end{array}$ & $\begin{array}{l}\text { PI } \\
\text { (1) }\end{array}$ & $\begin{array}{l}\text { BI } \\
\text { (1) }\end{array}$ & $\begin{array}{l}\text { All } \\
\text { (5) }\end{array}$ & $\begin{array}{l}\text { PR } \\
\text { (3) }\end{array}$ & $\begin{array}{l}\text { PI } \\
\text { (1) }\end{array}$ & $\begin{array}{l}\text { BI } \\
\text { (1) }\end{array}$ & $\begin{array}{l}\text { All } \\
\text { (5) }\end{array}$ & $\begin{array}{l}\text { PR } \\
\text { (3) }\end{array}$ & $\begin{array}{l}\text { PI } \\
\text { (1) }\end{array}$ & $\begin{array}{l}\text { BI } \\
\text { (1) }\end{array}$ & $\begin{array}{l}\text { All } \\
\text { (5) }\end{array}$ & $\begin{array}{l}\text { PR } \\
\text { (3) }\end{array}$ & $\begin{array}{l}\text { PI } \\
\text { (1) }\end{array}$ & $\begin{array}{l}\text { BI } \\
\text { (1) }\end{array}$ \\
\hline \multicolumn{17}{|l|}{$\underline{\text { Population }}$} \\
\hline ICMV 91059 & 1 & 1 & 1 & 5 & 1 & 1 & 1.5 & 6 & 3 & 3 & 4 & 3 & 2 & 3 & 2 & $\mathbf{1}$ \\
\hline SenPop & 2 & 2 & 3 & 3 & 3 & 3 & 4.5 & 2 & 5 & 6 & 5 & 4 & 5 & 7 & 4 & 5 \\
\hline ICMP 91751 & 3 & 3 & 4.5 & 6 & 2 & 2 & 3 & 4 & 2 & 1 & 2 & 2 & 3 & 1 & 3 & 3 \\
\hline ICMV 155 & 4 & 4 & 2 & 10 & 5 & $\overline{4}$ & 1.5 & 7.5 & $\mathbf{1}$ & 2 & $\mathbf{1}$ & $\overline{\mathbf{1}}$ & 1 & 2 & 1 & 2 \\
\hline ICMP 92591 & 5 & 7 & 4.5 & $\mathbf{1}$ & 4 & 5 & 4.5 & 1 & 4 & 4 & 3 & 5 & 5 & 5 & 5 & 6 \\
\hline AfPop 90 & 6 & 6 & 6 & 4 & 7 & 10 & 7 & 5 & 10 & 10 & 10 & 9 & 10 & 10 & 8 & 10 \\
\hline ICMP 87200 & 7 & 5 & 8 & 7 & 8 & 7 & 8 & 7.5 & 8 & 7.5 & 8.5 & 8 & 8 & 8 & 9 & 9 \\
\hline ICMP 87307 & 8 & 8 & 7 & 2 & 6 & 6 & 6 & 3 & 6 & 5 & 6 & 7 & 7 & 4 & 7 & 8 \\
\hline NWC C2 & 9 & 9 & 10 & 8.5 & 9 & 8 & 10 & 9 & 7 & 9 & 7 & 6 & 5 & 6 & 6 & 4 \\
\hline AfPop 88 & 10 & 10 & 9 & 8.5 & 10 & 9 & 9 & 10 & 9 & 7.5 & 8.5 & 10 & 9 & 9 & 11 & 7 \\
\hline LHGP & 11 & 11 & 11 & 11 & 11 & 11 & 11 & 11 & 11 & 11 & 11 & 11 & 11 & 11 & 10 & 11 \\
\hline
\end{tabular}

$\dagger$ All $=$ sum of ranks across all five environments; PR $=$ sum of ranks across three rainy season environments (not irrigated) at Patancheru; PI $=$ ranks in one irrigated hot dry season at Patancheru; BI = ranks in one irrigated cool dry season at Bhavanisagar. 


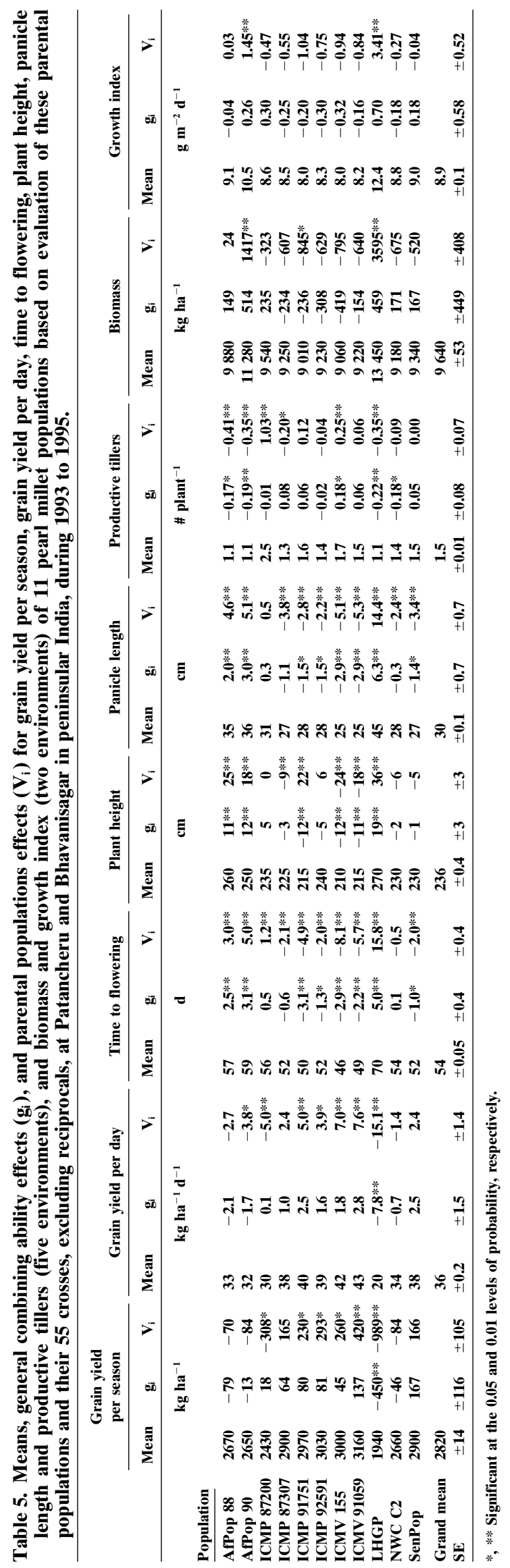

flowering, plant height, panicle length, and biomass. These results indicate that additive genetic effects were generally as important, if not more important, than dominance in controlling the observed agronomic characters in this set of diallel crosses. These results are probably due to the intrapopulation improvement methods used in developing the parental populations studied here, which are more effective at using additive genetic variation than that due to dominance, heterosis, or epistasis. These results agree with the findings of Singh et al. (1982) and Ouendeba et al. (1993) for grain yield, but are markedly different from those of Ouendeba et al. (1996) for forage yield. Zaveri (1982) also indicated that additive genetic variance was the most important component of genetic variance in a diallel cross of pearl millet populations.

General combining ability and $V_{i}$ effects for each of the eight agronomic characters are presented in Table 5. Predominance of GCA differences and significant $V_{i}$ effects suggest that variation among crosses was mainly due to additive rather than nonadditive gene effects. A more definitive separation of additive, dominance, and other non-additive genetic effects for these characters requires evaluation of additional populations, followed by the more comprehensive diallel variety-cross Analysis I of Gardner and Eberhart (1966). Although less than definitive, results from the current study indicate that these characters can be improved easily through breeding using a range of different intrapopulation and interpopulation selection procedures, and that hybrid cultivars based on crosses among these populations would not be expected to have clear performance advantages over open-pollinated cultivars before several cycles of interpopulation improvement.

\section{CONCLUSIONS}

Information from this study may apply to pearl millet breeding programs in Latin America, eastern and southern Africa, and South Asia. Our results reveal that genetic variability among the parental populations exists for some, but not all, agronomic characters studied, and much of this genetic variation appears to be additive in nature. This indicates that these parental populations can be intercrossed and recombined to develop broaderbased elite composites with high grain yield and sufficient genetic variability for their successful exploitation in future recurrent-selection programs. Parental populations with good performance per se and good performance in crosses for most agronomic characters included ICMP 87307, ICMP 91751, ICMP 92591, ICMV 155, ICMV 91059, and SenPop. These populations have good GCA for several agronomic characters and should be exploited by developing one or more broad-based composite populations with improved agronomic performance. The two feeder populations (AfPop 88 and AfPop 90) and broad-based genepool (LHGP) had poor GCA for most characters, but had positive combining abilities for panicle length. AfPop 90 and LHGP also had positive $V_{i}$ effects for biomass and growth index. However, these three parental populations and their 
crosses were generally very late to flower, had thick stems, and had very limited tillering capacity (as well as small grain size [data not shown]). They may prove more useful for developing fodder populations than dual-purpose (grain and stover) populations for Indian conditions, at least in the short and medium term. ICMP 87200 had poor GCA for most characters, but its population crosses with ICMP 87307 and ICMV 91059 had excellent grain yields (data not shown), suggesting that opportunities exist to exploit its genetic variability in breeding hybrids.

\section{ACKNOWLEDGMENTS}

The authors express their gratitude to James G. Coors and other anonymous reviewers for critical assessments of earlier drafts that greatly strengthened the clarity of this article.

\section{REFERENCES}

Appa Rao, S., M.H. Mengesha, and K.N. Reddy. 1998. Development and characterization of trait-specific genepools in pearl millet. Plant Gen. Resour. Newsl. 113:27-30.

Bramel-Cox, P.J., D.J. Andrews, F.R. Bidinger, and K.J. Frey. 1984 A rapid method of evaluating growth rate in pearl millet and its weedy and wild relatives. Crop Sci. 24:1187-1191.

Burton, G.W. 1983. Breeding pearl millet. Plant Breed. Rev. 1:162-182.

Eberhart, S.A., and C.O. Gardner. 1966. A general model for genetic effects. Biometrics 22:864-881.

Food and Agriculture Organization of the United Nations-International Crops Research Institute for the Semi-Arid Tropics. 1996. The world sorghum and millet economies: Facts, trends and outlook. FAO, Rome, and ICRISAT, Patancheru, India.

Gardner, C.O., and S.A. Eberhart. 1966. Analysis and interpretation of the variety cross diallel and related populations. Biometrics 22 : 439-452.

Hanna, W.W. 1990. Long term storage of Pennisetum glaucum (L.) R. Br. pollen. Theor. Appl. Genet. 79:605-608.
Kang, M.S., and H.G. Gauch (ed.) 1996. Genotype-by-environment interaction. CRC Press, New York.

Lynch, P.J., E.W. Rattunde, and K.J. Frey. 1995. Inheritance of vegetative growth index and related traits in pearl millet. Crop Sci. 35: 394-396.

Monyo, E.S. 1998. 15 years of pearl millet improvement in the SADC region. Int. Sorghum Millets Newsl. 39:17-33.

Ouendeba, B., G. Ejeta, W.E. Nyquist, W.W. Hanna, and A. Kumar. 1993. Heterosis and combining ability among African pearl millet landraces. Crop Sci. 33:735-739.

Ouendeba, B., W.W. Hanna, G. Ejeta, W.E. Nyquist, and J.B. Santini. 1996. Forage yield and digestibility of African pearl millet landraces in diallel with missing cross. Crop Sci. 36:1517-1520.

Pheru Singh, A.G.B. Raj, M.N.V.R. Rao, and J.R. Witcombe. 1994 Registration of 'ICMV 155' pearl millet. Crop Sci. 34:1409.

Rachie, K.O., and J.V. Majmudar. 1980. Pearl millet. The Pennsylvania State Univ. Press, London.

Rai, K.N., and K. Anand Kumar. 1994. Pearl millet improvement at ICRISAT-An update. Intl. Sorghum Millets Newsl. 35:1-29.

Rai, K.N., D.S. Murty, D.J. Andrews, and P.J. Bramel-Cox. 1999. Genetic enhancement of pearl millet and sorghum for the semiarid tropics of Asia and Africa. Genome 42:617-628.

Rattunde, H.F.W., E. Weltzein R., P.J. Bramel-Cox, K. Kofoid, C.T. Hash, W. Schipprack, J.W. Stenhouse, and T. Presterl. 1997. Population improvement of pearl millet and sorghum: Current research, impact, and issues for implementation. p. 188-212. In Proc. Int. Conf. Genetic Improv. Sorghum Pearl Millet, Lubbock, TX. 22-27 Sept. 1996. INTSORMIL Publ. 97-5. INTSORMIL and ICRISAT, Lincoln, NE.

Singh, F., R.L. Kapoor, and H.R. Dhaiya. 1982. Combining ability analysis for yield and its attributes in pearl millet. J. Res. Haryana agric. Univ. 12:644-648.

Steel, R.G.D., and J.H. Torrie. 1980. Principles and practices of statistics: A biometrical approach. 2nd ed. McGraw Hill, New York

Weltzien Rattunde, E., P.J. Lynch, and H.F.W. Rattunde. 1995. Utilization of pearl millet germplasm via formation and improvement of two high growth rate populations. Int. Sorghum Millets Newsl 36:31-34.

Zaveri, P.P. 1982. Genetic studies in relation to population improvement in pearl millet. Ph.D. thesis. College of Agriculture, Punjab Agricultural Univ., Ludhiana, India. 